\title{
The Future of Pensions in Taiwan
}

\author{
Yung-Ming Shiu \\ Department of Finance, Tunghai University, Taichung, Taiwan. \\ E-mail: yungming@thu.edu.tw
}

Many articles relating to the issue of pension reforms are devoted to the pension systems in Western countries. Very few papers address this issue in the context of Asian countries, especially developing ones. The main purpose of this article is to evaluate the current and future pension situation in Taiwan and its possible effects on, for example, life insurance, the development of the Fourth Pillar, and the extension of working life. The experience of Taiwan should be of interest to policymakers, insurance firms, and the authorities concerned.

The Geneva Papers (2005) 30, 593-603. doi:10.1057/palgrave.gpp.2510050

Keywords: pension reform; life insurance; the fourth pillar; extension of working life

\section{Introduction}

As shown in Figure 1, the proportion of the elderly population in most Asian countries (a notable exception being Japan) is generally lower than that in Western countries. Most countries in Asia, especially developing ones, do not have a sound pension system in place due in part to the prominent difference in the age structure. Nevertheless, because of demographic transition, the issue of how to build a sustainable pension system is gradually coming to the fore. A number of important lessons can be learned by comparing pensions in Western developed countries such as France, Germany, and the United Kingdom, etc. Many articles relating to the pensions in these countries have been published in the previous issues of The Geneva Papers on Risk and Insurance - Issues and Practice on the Four Pillars. It is worth noting that very few papers address this issue in the context of Asian developing countries. One of the main contributions of this article is to fill up the gap in the literature. The primary reason why Taiwan is chosen for study is that the Taiwanese population is progressively ageing and its total fertility rate has reached a record low. It is expected that the situation faced by Taiwan will sooner or later be faced by other Asian developing countries. Consequently, the case of Taiwan should be of interest to the authorities concerned, policymakers, and the insurance industry. The specific objectives of the paper are two-fold: first, to evaluate the current and future pension situation in Taiwan; second, to analyse the possible effects of the reform on life insurance, women, extension of working life, and the fourth pillar.

Although Taiwan has achieved an economic miracle, its building of a four-pillar pension system is still at a relatively preliminary stage. This article aims at presenting the main features of the reform concerning a strengthening of the second pillar and a development of the fourth pillar. The next section presents the existing system and the context of the reform. The following section is devoted to analyzing the main features 


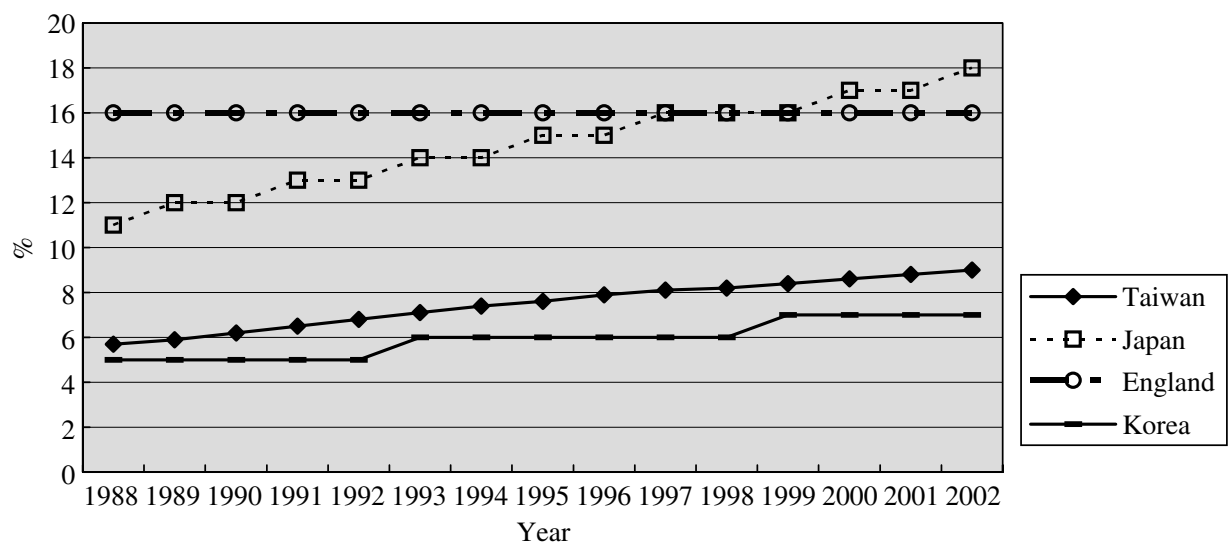

Figure 1. The proportion of population aged 65 and over. Source: World Population Estimation, Council for Economic Planning and Development, Taiwan, 2004.

of the reform, while the penultimate section gives a critical appraisal of its impact on a number of aspects. The final section summarizes and concludes the paper.

\section{The existing pension system and the context of the reform}

Why does Taiwan propose sweeping reforms of the pension system? There are two main reasons for this. First of all, Taiwan will be undergoing the greatest demographic transition in the foreseeable future. Second, the existing system has incurred a number of criticisms. The rest of this section will analyze the situation faced by the Taiwanese government from these two points of view.

According to demographic projections of the Council for Economic Planning and Development, the next five decades will witness the following major changes in demographic trends. Table 1 reports the detailed results:

- Population growth will progressively decline: the population growth rate, which was 0.4 per cent in 2004, could be -1.3 per cent in 2051 .

- Life expectancy will gradually increase between 2004 and 2051: men's life expectancy which was 73.5 years in 2004 could be 79.2 in 2051; women's life expectancy which was 79.2 years, could be 86.1 in 2051 .

- The elderly population will increase dramatically: the proportion of population aged 65 years and over which was 9.4 per cent in 2004, could be 35.5 per cent in 2051 .

- The elderly dependency ratio, measured by the number of people aged 65 years and over relative to the number aged 15-64 will experience a tremendous boom: the ratio which was 13.2 per cent in 2004, could be as high as 76.5 per cent in 2051.

- The total fertility rate will reach a record low: the rate of 1.17 in 2004 could be as low as 0.74 in 2051 .

There are two ongoing trends that can be identified from Table 1. The first is that fertility is currently below replacement level. The second trend is that the Taiwanese 
Table 1 Demographic projection between 2004 and 2051

\begin{tabular}{|c|c|c|c|c|c|c|}
\hline Year & $\begin{array}{c}\text { Population } \\
\text { (in thousands) }\end{array}$ & $\begin{array}{c}\text { Population } \\
\text { growth rate } \\
(\%)\end{array}$ & $\begin{array}{l}\text { Life } \\
\text { expectancy } \\
\text { (years) }\end{array}$ & $\begin{array}{c}\text { Proportion of } \\
\text { elderly population } \\
(\%)\end{array}$ & $\begin{array}{c}\text { Elderly } \\
\text { dependency } \\
\text { ratio }(\%)\end{array}$ & $\begin{array}{c}\text { Total fertility } \\
\text { rate }\end{array}$ \\
\hline 2004 & 22,755 & 0.4 & $\begin{array}{l}\text { Male: } 73.5 \\
\text { Female: } 79.2\end{array}$ & 9.4 & 13.2 & 1.17 \\
\hline 2011 & 23,100 & 0.3 & $\begin{array}{l}\text { Male: } 76.8 \\
\text { Female: } 83.4\end{array}$ & 10.6 & 14.4 & 0.95 \\
\hline 2021 & 22,836 & 0 & $\begin{array}{l}\text { Male: } 78.3 \\
\text { Female: } 85.2\end{array}$ & 16.5 & 23.5 & 0.74 \\
\hline 2031 & 21,772 & -0.4 & $\begin{array}{l}\text { Male: } 78.8 \\
\text { Female: } 85.7\end{array}$ & 24.3 & 38.9 & 0.74 \\
\hline 2051 & 16,797 & -1.3 & $\begin{array}{l}\text { Male: } 79.2 \\
\text { Female: } 86.1\end{array}$ & 35.5 & 76.5 & 0.74 \\
\hline
\end{tabular}

Source: Taiwanese Population Forecast from 2004 to 2051, Council for Economic Planning and Development, Taiwan, 2004.

population is ageing dramatically, the long-term results of a below-replacement fertility rate. The total fertility rate was 1.17 in 2004 . Fertility is expected to probably decline further in the future, in particular if the Taiwanese government does not take measures to boost fertility.

Since 1984, the retirees in Taiwan may be able to obtain two retirement benefits: elderly benefits from the Bureau of Labour Insurance and occupational pensions from their employer. Elderly benefits are actually labour insurance benefits under the Labour Insurance Act. The longer the insured person is with the Labour Insurance scheme, the higher the benefits he/she can obtain when retiring. In accordance with the Act, the retired employee can get a one time average monthly labour insurance salary for each year under 15 insurance years, while the worker can get double for every year over 15 insurance years. Workers may apply for elderly benefits if the following conditions are met: (1) if the insured (the official age is 60 for men and 55 for women) has been with the labour insurance programme for 1 year and retires; (2) if the insured is over 55 years and has been with the programme for 15 years; (3) if the insured has continuously been with one firm and the programme for 25 years; (4) if the insured is over 50 years and has been with the programme for 25 years; (5) if the insured is over 55 years and has been in the hazardous business requiring physical strength for over 5 years. As long as the worker satisfies any of the above entitlement conditions, he/she can get an old age-pension from the Bureau of Labour Insurance.

Labour pensions are in fact occupational pensions under the Labour Standards Law. According to the Law, employees may voluntarily retire (1) if they are 55 years of age or above, and have been with the company for more than 15 years; (2) if they have been with the company for more than 25 years. The employer may legally dismiss workers (1) if they are 60 years or above; (2) if they are mentally or physically disabled 
and are not up to their job. The pensions, which the retirees may receive, depend on how long they have been with the firm. According to Article 55 of the Law, for each of the working years employees are with the company, they obtain two times their average monthly salary, while for each of the working years over 15 , they only receive once the average monthly wage.

The existing Labour Standards Law was enacted in 1984. Over the past two decades a number of problems concerning the pensions have gradually emerged. The first is that under the existing pension system it is difficult for the workers to meet the retirement conditions specified in the Law and to receive pensions to which they are entitled. The majority of employees will not be able to receive pensions when they retire. The possible reasons behind this are as follows: (1) workers have to be with the same company for 25 years or 15 years if they are over 55 years in accordance with the Law. Nevertheless, 95 per cent of the enterprises in Taiwan are small-to-medium businesses and their average life is only 13 years. The Taiwanese workers' average number of working years with one firm is only 8.3 years. This means that most employees cannot obtain pensions unless they are employed by state-owned companies or large enterprises; (2) most of the employers did not contribute to pension provisions in accordance with the Law. It is estimated that about 90 per cent of the Taiwanese workers cannot receive any occupational pensions; (3) the accumulated pension contributions from the employer, if any, cannot be transferred if the employee changes his or her job and works for another firm.

The second problem is that under the Labour Standards Law the amount of retirement pensions depends on the retiree's qualified working years and his or her average monthly salary. Employers are required to pay a certain percentage (from 2 to 15 per cent) of workers' average monthly salary as pension provisions. Nevertheless, most employers, especially from medium and small-sized enterprises, have not contributed as required. Moreover, this defined-benefits system makes it difficult for employers to estimate their employees' pension costs, and thus increases the chance of exposing them to financial risk.

Third, once unemployed, it is extremely difficult for employees of mature age to return to work markets. Employers prefer not to hire older workers with much experience and great skills because their future working life is relatively short compared with young workers. The principle of employment equality cannot always be observed. This is an obstacle for older workers to enter or re-enter the employment market.

Finally, some employers illegally dismiss their employees before they meet the requirements in order not to pay pensions. This often makes the employee-employer relationship worse and other employees feel insecure and tense.

\section{The main features of the reform}

In June 2004, the Labour Pension Bill was passed and the Labour Pension Act was implemented on 1 July 2005. The Act has two most distinct features. First, the definedcontribution plan is adopted. According to this plan, monthly contributions from the 
employers to their individual pension account cannot be less than 6 per cent of the employee's salary. The employee can voluntarily contribute any amount less than 6 per cent of his or her monthly salary to the same account. With a view to encouraging employees to save for their own retirement, the contribution by the employee is taxfree. The second feature is that the pension is portable (the new employer can continue to contribute to the account when the employee changes job). As stated previously, it has been difficult for employees to receive pensions. The portable pension system makes it possible for retirees to receive pensions without worrying about the possible bankruptcy of their firm.

Under the Labour Pension Act, employees can make choices about their pensions. They can opt to receive pensions under the Labour Standards Act if they wish. More specifically, according to Article 8 of the Labour Pension Act, employees who were subject to the Labour Standards Law prior to the implementation of the Labour Pension Act and still work for the same company after the enforcement of this Act may choose the old pension scheme under the Labour Standards Law. Since most state-owned businesses and large privately owned enterprises made labour pension provisions in accordance with the Labour Standards Act, their workers will be able to receive pensions when retiring. In addition, there will be two alternatives, including the Individual Pension Account Scheme and Pension Insurance Scheme. The former is set as the main pension scheme and the latter as the auxiliary one. These two schemes are discussed as follows.

\section{The individual pension account scheme}

The Individual Pension Account Scheme is an arrangement for employers, on their own or with a group of other employers, to provide pensions for their employees when they retire. According to the Labour Pension Act, employers are obliged to pay no less than 6 per cent of their employee's salary as labour pension contributions to the worker's account. Employees may voluntarily pay contributions, up to 6 per cent of their monthly wages for their own retirement. These contributions from workers may be deducted from their taxable income. All the contributions paid by the employee and his or her employer(s) are saved in an account, called Individual Pension Account, with the Bureau of Labour Insurance. The Bureau will manage administrative affairs including the contracting out of the management of the pension funds. With a view to ensuring the basic level of the retirees' lives, the Taiwanese Government, in accordance with Article 23 of the Act, has guaranteed a minimum rate of return. In the event of any deficiency, the National Treasury shall make up the shortfall.

The employees aged 60 years or above are entitled to a monthly pension payment if their qualified years are equal to or more than 15 years. The monthly payment depends on the investment performance of the pension fund, the annuity table, average life expectancy, and interest rates, etc. Retired employees are required to purchase annuity products from insurers. For those whose qualified years are less than 15 years, a lump sum payment will be made. If the employee dies before receiving any pensions, his/her survivors or designated persons may claim a lump sum payment. 


\section{The annuity scheme}

In addition to the options mentioned above, there is another choice for large firms with over 200 employees. These firms may purchase annuity products for their employees using employers' contributions, which may not be less than 6 per cent of the monthly wages of their employees. It is worthwhile to note that the adoption of this scheme should be approved by trade unions. For the companies without unions, at least half of the employees have to agree to participate in such a scheme.

For comparison purposes, the differences in the existing and new pension systems are summarized in Table 2.

As indicated, under the existing system, most workers are unlikely to receive occupational retirement benefits when they retire. Although it is certain that workers can get their benefits under the new system, the amounts are generally less than those under the existing system. An illustrated example is presented in Table 3.

\section{The effects of the reform}

\section{Life insurance}

The pension reform has a great impact on life insurance. First, since most employees will choose the Individual Pension Account Scheme, a large amount of money will be accumulated in the fund formed under this scheme. Qualified life insurers as well as other financial institutions will be allowed to manage the fund. In order to participate in the huge and potentially profitable business, life insurance firms have to reinforce their capacity of asset and liability management (ALM). The overall and sound structure of ALM should be in place for firms to take on the forthcoming challenges. Second, large enterprises with more than 200 employees may choose to purchase annuity products from life insurers. It is estimated that around two million employees would opt for this scheme. The strong demand for annuities will probably create a new and important market for life insurers. Third, a need for thinking about their retirement lives will awaken employees after the introduction of the new pension system. Since the pensions received will not be sufficient for lives as retirees, employees will probably consider buying life insurance policies such as endowment, variable life, and universal life contracts. If this is the case, life firms will have to re-educate their agents on retirement planning, especially on how to employ insurance to cope with the financial needs after retirement. With a view to providing their policyholders with good services, it is essential for agents in the competitive market to be more professional than ever.

\section{Women and the fourth pillar}

In Asia, women rather than men have to temporarily give up their full-time jobs, if necessary, to take care of their families, especially while children are very young or parents old or sick. As shown in Figure 2, the female labour force participation rate is generally lower than the male participation rate. According to the statistics of the year 
Table 2 Comparison between the existing and new pension systems

\begin{tabular}{|c|c|c|}
\hline & Existing pension system & New pension system \\
\hline Law & The Labour Standards Law & The Labour Pension Act \\
\hline Type & Defined-benefits & Defined-contributions \\
\hline $\begin{array}{l}\text { Employer's } \\
\text { contributions }\end{array}$ & $\begin{array}{l}2-15 \text { per cent of the worker's } \\
\text { monthly average wages }\end{array}$ & $\begin{array}{l}\text { Contributions from the employer shall be not less than } \\
6 \text { per cent of the worker's monthly average wages }\end{array}$ \\
\hline $\begin{array}{l}\text { Employee's } \\
\text { contributions }\end{array}$ & None & $\begin{array}{l}\text { Contributions from employees shall be equal to or less } \\
\text { than } 6 \text { per cent of their wages and are deducted from } \\
\text { taxable income }\end{array}$ \\
\hline Qualified years & Not portable & Portable \\
\hline $\begin{array}{l}\text { Retirement } \\
\text { conditions }\end{array}$ & $\begin{array}{l}\text { The worker has to be with the } \\
\text { company for } 25 \text { years or } 15 \\
\text { years if he/she is over } 55 \text { years }\end{array}$ & $\begin{array}{l}\text { Three alternatives: } \\
\text { (1) The worker may choose to retire under the existing } \\
\text { system } \\
\text { (2) The Individual Pension Account Scheme } \\
\text { (3) Annuity Scheme }\end{array}$ \\
\hline Benefits & $\begin{array}{l}\text { The worker can receive two } \\
\text { times of monthly average wage } \\
\text { for each year of service under } \\
15 \text { and one time for each year } \\
\text { of service over } 15\end{array}$ & $\begin{array}{l}\text { (1) The existing system: same as the benefits listed on } \\
\text { the left. } \\
\text { (2) The Individual Pension Account Scheme: the } \\
\text { accumulated principal and accrued income } \\
\text { (3) Annuity Scheme: The amount of benefits depends } \\
\text { on the terms and conditions of the contract }\end{array}$ \\
\hline $\begin{array}{l}\text { Payment } \\
\text { options }\end{array}$ & A lump sum & $\begin{array}{l}\text { Two alternatives: } \\
\text { (1) Monthly payments } \\
\text { (2) A lump sum }\end{array}$ \\
\hline Advantages & $\begin{array}{l}\text { Employees: } \\
\text { (1) The existing pension system } \\
\text { is easy to understand } \\
\text { (2) The amount of benefits is } \\
\text { generally larger than that } \\
\text { under the new pension } \\
\text { system } \\
\text { Employers: } \\
\text { (1) The degree of workers' } \\
\text { mobilization is low }\end{array}$ & $\begin{array}{l}\text { Employees: } \\
\text { (1) The qualified years are portable } \\
\text { (2) Relatively easy for elderly workers to get a job } \\
\text { Employers: } \\
\text { (1) Easy to estimate the pension cost } \\
\text { (2) May consider hiring skilled, though old, workers }\end{array}$ \\
\hline Disadvantages & $\begin{array}{l}\text { Employees: } \\
\text { (1) Difficult to receive pensions } \\
\text { (2) Difficult for elderly workers } \\
\text { to get a job } \\
\text { Employers: } \\
\text { (1) Difficult to estimate the } \\
\text { labour pension cost } \\
\text { (2) Employers bear the } \\
\text { investment risk }\end{array}$ & $\begin{array}{l}\text { Employees: } \\
\text { (1) Employees bear the investment risk } \\
\text { (2) The new pension system is relatively complicated } \\
\text { Employers: } \\
\text { (1) The degree of workers' mobilization is high }\end{array}$ \\
\hline
\end{tabular}


The Geneva Papers on Risk and Insurance - Issues and Practice

600

Table 3 Retirement benefits under the existing and old pension systems

\begin{tabular}{lrrr}
\hline Current wage (\$) & 30,000 & 40,000 & 50,000 \\
Annual rate of return on pension funds (\%) & 6 & 6 & 6 \\
Wage growth rate (\%) & 3 & 3 & 3 \\
Contribution rate (\%) & 6 & 6 & 6 \\
Working years & 20 & 20 & 20 \\
Retirement benefit under the new system (a lump sum) & $1,059,772$ & $1,412,321$ & $1,775,588$ \\
Monthly Retirement benefit under the new system & 7,555 & 10,068 & 12,658 \\
Retirement benefit under the existing system (a lump sum) & $1,841,175$ & $2,454,900$ & $3,068,625$ \\
\hline
\end{tabular}

Source: Own calculation.

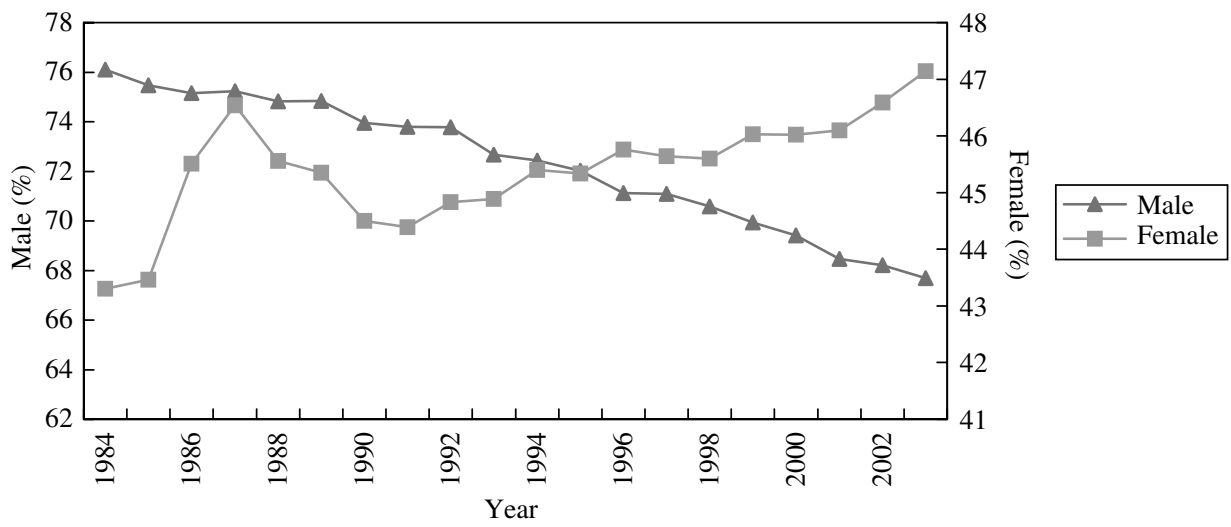

Figure 2. The labour force participation rate in Taiwan (1984-2003). Source: Human Resource Statistics Yearbook, Directorate-General of Budget Accounting and Statistics, Taiwan, 2004.

of 2003 (published by the Directorate-General of Budget Accounting and Statistics), the women labour force participation rate in Taiwan was 47 per cent. Although this figure was lower than that of most developed Western countries, it was the third highest among Asian countries and only second to South Korea (49 per cent) and Japan (48 per cent). In these two countries, most women who previously worked would return to labour markets once they no longer had family responsibilities. Nevertheless, this is not the case in Taiwan. Most female workers retire permanently after pregnancy. Only 24 per cent of them go back to the employment market (Lin, 2004). It is found that the participation rate of middle-aged women was significantly lower than that in the two other countries. One of the possible reasons for this was that the previously accumulated qualified years for pensions under the old pension system are void after a period of interruption. After the Labour Pension Act is implemented, the qualified years of the working women can then be accumulated and transferred when changing jobs. The rate of women participation is expected to increase to a certain extent.

The other identifiable feature from Figure 2 is that the difference between female and male labour force participation rates is decreasing. The trend of female participation rate is upward. This highlights the importance of the female workforce. 


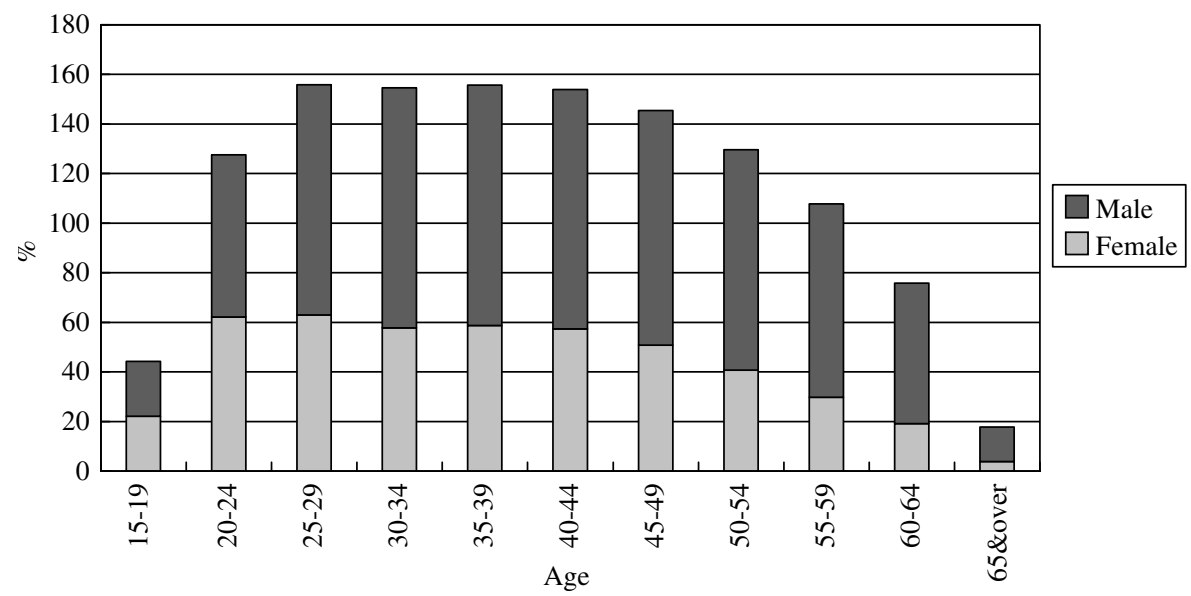

Figure 3. The average labour force participation rate in different age groups in Taiwan (1984-2003). Source: Human Resource Statistics Yearbook, Directorate-General of Budget Accounting and Statistics, Taiwan, 2004.

Figure 3 shows the average female and male labour force participation rates by agegroup from 1984 to 2003. It is noted that there are low levels of labour force participation among mature-age employees, especially women. Female retirement or withdrawal from the labour force comes earlier than male retirement. The female participation rate fell from 50 per cent for those aged 45-49 to 40 per cent for those aged $50-54$, to 29 per cent for those aged 55-59, to 19 per cent for those aged 60-65. The decline in the female labour force participation rate of older workers in Taiwan is mirrored in other developed countries.

In addition, atypical employment has become more and more common in the current job market. This type of employment includes part-time, temporary, dispatched, and outsourcing work. Since this kind of job may strike a balance between women's working and family lives, the proportion of female workers in the atypical employment market is greater than that of male workers.

The funding of pensions is traditionally based on three pillars, the basic state pensions (the first pillar), the supplementary occupational funded pensions (the second pillar), and private pensions, insurance and savings (the third pillar). With a view to supplementing the income from the existing three pillars, The Geneva Association has been advocating the concept of a "fourth pillar". This pillar relates to the extension of working life, mainly on a part-time basis. In Taiwan, under the Labour Standards Law, part-time and temporary workers seldom receive pensions and they will greatly benefit from the new pension system.

\section{Extension of working life}

Under the Labour Standards Law, retirees shall be paid two times their monthly average wage for each year of service under 15 and one time for each year of 
602

service over 15. Also, the maximum amount of the pensions workers may obtain is 45 times their average monthly wage. In this case, the employee receives no pensions for any service years exceeding 30. When the official retirement age is reached, employees may withdraw from the job markets in order to get pensions. The existing system actually discourages workers of mature age from remaining in the workforce.

Under the Labour Pension Act, the defined-contribution plan is adopted. Employers have to continue making contributions even if workers have been working for over 30 years. The longer the workers remain in the workforce, the more benefits they get when they retire. It is anticipated that workers will be more willing to extend their working life after the Act is implemented. Moreover, a pension in general must not be drawn before the official retirement age (60 years) is reached. Under certain circumstances, which will be stipulated later, employees may claim pension for emergency use.

\section{Conclusion}

Developed countries, especially those in Europe, are confronting the problem of the sustainability of pensions. This problem arose due in part to the European culture of early exit from the labour market among elderly workers in the 1970s. On the whole, the populations in Western developed countries are ageing. The early retirement of the workers has put a great strain on the funding of pensions. In order to address this issue, since 1987 The Geneva Association has been advocating the importance of the fourth pillar and the extension of work-life, with a view to strengthening the financing of pensions and supplementing income from the three existing pillars, the state pension, the occupational pension, and the individual savings. Compared with European developed countries, Taiwan has a relatively young population. In 2005, 13 per cent of the Taiwanese population was aged 60 and above. As the average life expectancy (men: 73 years; women: 78 years) in Taiwan has been increasing significantly over the past few decades and the population is ageing, it is anticipated that sooner or later Taiwan will be undergoing what Western developed countries are currently experiencing. In order to deal with this issue, the Taiwanese government has proposed a series of measures that have been described in previous sections.

In terms of the development of occupational pensions, Taiwan is still at a preliminary stage compared with Western OECD countries. This article presented and analysed the pension reform in Taiwan and its possible effects on life insurance, the development of the Fourth Pillar, and the extension of working life. The case of Taiwan should be of interest to policymakers, insurance firms, and the authorities concerned.

To sum up, there is a common trend across the world towards increasing the official age of retirement. Moreover, older workers are encouraged to remain in the workforce and options for flexible employment are opening up. These features are expected to become more prominent in the foreseeable future, as older people will soon account for a greater proportion of the population. 


\title{
References
}

Council for Economic Planning and Development (2004) Taiwanese Population Forecast from 2004 through 2051, Taiwan: The Council for Economic Planning and Development.

Directorate-General of Budget Accounting and Statistics (2004) 2003 Human Resource Statistics Yearbook, Taiwan: The Directorate-General of Budget Accounting and Statistics.

Lin, Yi-Guan (2004) The Taiwanese female workers under the new economy, unpublished thesis, Chung-Gen University, Taiwan.

\begin{abstract}
About the Author
Yung-Ming Shiu is Assistant Professor in the Management College at Tunghai University, Taiwan. He teaches insurance and risk management, and is the Director of the Centre for the Research of Banking and Finance. Dr. Shiu's research focuses on the areas of corporate hedging, risk management, and dynamic financial analysis. His research has appeared in a number of scholarly and trade journals such as Applied Economics Letters and British Actuarial Journal.
\end{abstract}

